DOI: 10.18697/ajfand.73.15875

\title{
EFFECT OF BAP, NAA AND GA3, EITHER ALONE OR IN COMBINATION, ON MERISTEM CULTURE AND PLANTLET ESTABLISHMENT IN SWEET POTATO (CV BRONDAL)
}

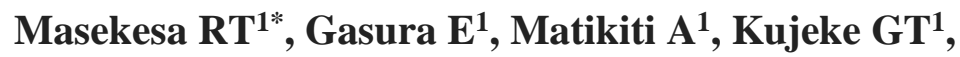
Ngadze $\mathrm{E}^{1}$, Icishahayo $\mathrm{D}^{1}$, Chidzwondo $\mathrm{F}^{2}$ and AI Robertson ${ }^{1}$

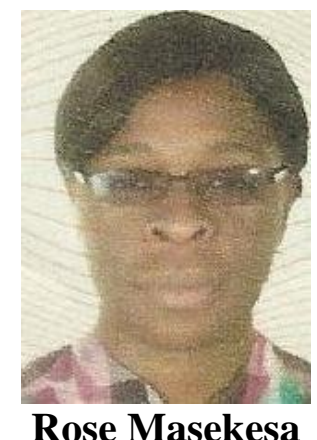

*Corresponding author email: rosetaffy1@gmail.com

${ }^{1}$ Department of Crop Science, Faculty of Agriculture, University of Zimbabwe, P. O. Box MP 167 Mount Pleasant, Harare, Zimbabwe

${ }^{2}$ Department of Biochemistry, Faculty of Science, University of Zimbabwe, P. O. Box MP 167 Mount Pleasant, Harare, Zimbabwe 


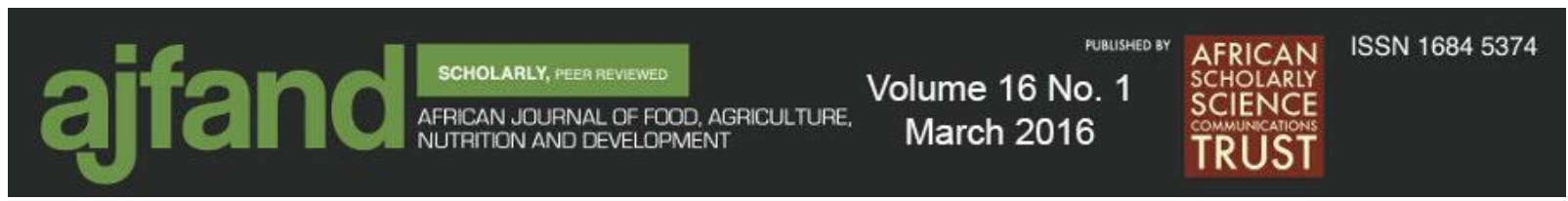

\section{ABSTRACT}

In Zimbabwe, the average sweet potato yield (6 t/ha) is relatively low when compared to Asian counterparts (17 t/ha). These low crop yields have been blamed on weevil infestations and viral infections which account for 60-90\% of sweet potato yield losses in Africa. Meristem tip culture, a Centre for Potato Improvement (CIP) initiated tissue culture technique, has been widely used to eradicate viruses from clonally propagated crops and has been noted to be one of the instrumental techniques that helped China to increase sweet potato yields. In an effort to adopt the meristem tip culture technique for the production of virus-free planting material of a local sweet potato ( $c v$ Brondal), a study was conducted to evaluate the effect of Benzylamino purine (BAP), 1-Naphthaleneacetic acid (NAA) and Gibberellic acid $\left(\mathrm{GA}_{3}\right)$ (either alone or in combination) on cultured Brondal meristems. The different hormonal treatments were assessed on the following parameters: plantlet regenerative capacity, multiple plantlet production, shoot height, average leaf number per shoot and average node number per shoot, ten weeks after meristem culture. All treatments containing a combination of BAP $\left(1 \mathrm{mg}^{-} \mathrm{L}\right)$ and $\mathrm{GA}_{3}$ (at either $5 \mathrm{mg}^{-} \mathrm{L}, 10 \mathrm{mg}^{-} \mathrm{L}$, or $\left.20 \mathrm{mg}^{-} \mathrm{L}\right)$ had a significantly $(\mathrm{p}<0.01)$ higher plantlet regenerative capacity of 33-66\% when compared to other treatment combinations. Only treatments, $10 \mathrm{mg}^{-} \mathrm{L} \mathrm{GA}_{3}+1 \mathrm{mg}^{-} \mathrm{L}$ BAP and $20 \mathrm{mg}^{-} \mathrm{L} \mathrm{GA}_{3}+1 \mathrm{mg}^{-} \mathrm{L}$ BAP were capable of inducing multiple plantlet formation, producing an average of three plantlets/meristem and two plantlets/meristem respectively. Overall, treatment $10 \mathrm{mg}^{-} \mathrm{L} \mathrm{GA}_{3}+1 \mathrm{mg}^{-} \mathrm{L}$ BAP gave rise to significantly $(\mathrm{p}<0.01)$ taller shoots $(20 \mathrm{~mm})$ compared to the rest of the treatments used. For average leaf number per shoot, all GA 3 treatments $\left(5 \mathrm{mg}^{-} \mathrm{L}, 10 \mathrm{mg}^{-}\right.$ $\mathrm{L}$, or $\left.20 \mathrm{mg}^{-} \mathrm{L}\right)$ supplemented with $1 \mathrm{mg}^{-} \mathrm{L}$ BAP gave significantly $(\mathrm{p}<0.01)$ higher numbers of leaves (six leaves/shoot) than the rest of the treatments. Treatments $10 \mathrm{mg}^{-} \mathrm{L}$ $\mathrm{GA}_{3}+1 \mathrm{mg}^{-} \mathrm{L}$ BAP and $20 \mathrm{mg}^{-} \mathrm{L} \mathrm{GA}_{3}+1 \mathrm{mg}^{-} \mathrm{L}$ BAP gave rise to the highest number of nodes per shoot, producing an average of three nodes per shoot. In sharp contrast to treatments containing a combination of $\mathrm{BAP}$ and $\mathrm{GA}_{3}$, all treatments containing a combination of BAP and NAA performed poorly in all parameters tested for plant regeneration of Brondal sweet potato variety. In conclusion, the best hormonal treatment for culturing Brondal meristems proved to be $10 \mathrm{mg}^{-} \mathrm{L} \mathrm{GA}_{3}+1 \mathrm{mg}^{-} \mathrm{L}$ BAP.

Key words: Ipomoea batatas, meristem, regeneration, Benzylamino purine, Gibberellic acid, 1-Naphthaleneacetic acid 


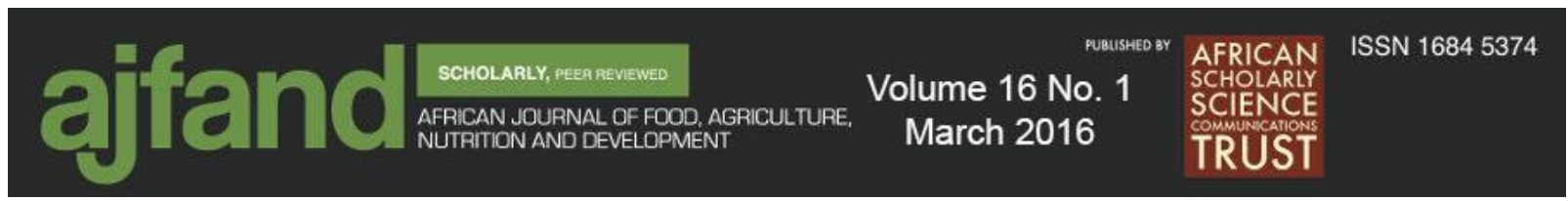

\section{INTRODUCTION}

Sweet potato, botanically known as Ipomoea batatas is a dicotyledonous, tuberous root crop that is grown extensively in the humid tropical, subtropical and warm temperate regions of the world [1,2]. Belonging to the Convolvulaceae family [3], sweet potato is the only food crop of importance in a family of otherwise weedy species [4]. The estimated annual global production of sweet potato is above 127 million tonnes, making sweet potato a multi-billion dollar business [5]. To date, China is currently the largest producer of sweet potato, with 108 million tonnes per year on approximately 5 million hectares of land. China's 108 million tonnage translates to $84 \%$ of the total world sweet potato production [5]. Top producers in Africa are Uganda at 1.7 million tonnes/year, Kenya 1 million tonnes/year while Rwanda produces 900000 thousand tonnes/year [6].

In comparison, Zimbabwe's own modest production levels of 10000 tonnes/year is relatively low [6]. According to the Ministry of Lands and Agriculture, (AREX) [7], the main constraints to achieving high yields of sweet potato in the country are three fold: shortage of planting material, limited access to high yielding varieties, and biotic factors such as pests and disease. Weevil infestation and viral infections account for yield losses of up to $90 \%$ and $60 \%$, respectively [8]. Weevil infestations can be addressed by using a combination of cultural and chemical control measures. For viral infections a tissue culture technique known as meristem tip culture has been successfully used in cassava, potato, sweet potato, papaya and Livingstone potato for the exclusion of viruses [9].

Meristem tip culture, also known as virus elimination, is a technique based on the principal of pathogen exclusion where cells or tissues that do not harbour viruses are cultured and allowed to regenerate into a fully functional plant [9]. As the plant would have originated from disease free cells, the regenerated plant will also be disease free. Therefore, when disease free planting material is used, the physiological potential (such as photosynthetic capacity) of the crop is fully expressed, allowing the crop to reach its full yield potential [9].

Sweet potato regeneration using meristems as explants has been described for many varieties and many researchers in the world have managed to develop regeneration systems that work in their specific environments [10]. However, regeneration tends to be genotype specific; thus there is need to try and adapt established protocols and modify them if necessary, to suit local conditions and local varieties.

In light of the fact that China owes in part, its sweet potato success story to the meristem culture technique [11], the objective of the study was to develop a regeneration protocol for Zimbabwean sweet potato ( $c v$ Brondal) using meristems as explants. Specifically, the effects of BAP, NAA and $\mathrm{GA}_{3}$ used either alone or in combination were evaluated for their effect on plantlet regenerative capacity, multiple plantlet production, shoot height, average leaf number per shoot and average node number per shoot at ten weeks after meristem culture. 


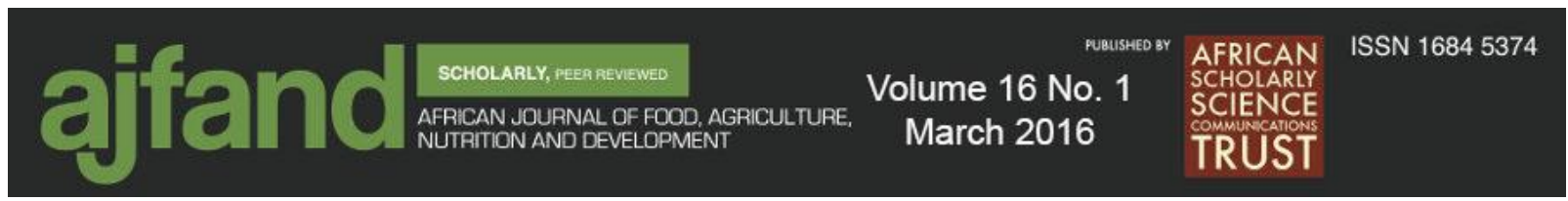

\section{MATERIALS AND METHODS}

Planting material: Field growing sweet potato ( $c v$ Brondal) vines were obtained from Agribiotech, Harare, Zimbabwe. All the leaves attached to the vines were removed and the leafless vines were cut into three nodal sections, $4-6 \mathrm{~cm}$ long. The nodal cuttings were then washed with soapy water (sunlight dishwashing liquid) to remove surface debris adhering to the explants. The Brondal segments were then placed under running tap water for three hours to create an isotonic solution inside the segment. After the wash stage, the Brondal segments were surface sterilised in $20 \%$ commercial bleach for 15 minutes. This procedure was performed in the Laminar Airflow Hood (L. A. H.) (model Slee London). The sterilised vine segments were then rinsed thrice with sterile distilled water to remove the disinfecting commercial bleach.

A stereomicroscope (Wild M3B Heerbrugy, Switzerland) was used to locate and magnify (10x by 16x) the meristematic region on the sterilized stem section. After sterilising the forceps and blade with a Bead steriliser (Simon Keller AG, steri 350) $\left(250^{\circ} \mathrm{C}\right.$ ), the forceps and blade were used to isolate the meristematic dome together with 1-2 leaf primodia sets and thus protecting it. The isolated meristem was then placed on to prepared Murashige and Skoog (MS) [12] media.

Culture media preparation: Meristem explants were cultured onto solid MS media containing prescribed salt nutrients supplemented with $100 \mathrm{mg}^{-} \mathrm{LMyo}$-inositol, $2 \mathrm{mg}^{-\mathrm{L}}$ Glycine, $1 \mathrm{mg} / \mathrm{L}$ Nicotinic acid, $1 \mathrm{mg} / \mathrm{L}$ Pyrodoxine, $0.2 \mathrm{mg}^{-} \mathrm{L}$ Thiamine, $30 \mathrm{~g}^{-} \mathrm{L}$ sucrose and $10 \mathrm{~g}^{-} \mathrm{L}$ agar. Growth regulators were added to the MS media to make up the respective treatments (as outlined in Table 1). The NAA stock solution (1 $\left.\mathrm{mg}^{-} \mathrm{ml}\right)$ was prepared by dissolving $50 \mathrm{mg}$ of NAA in a few drops of $0.5 \mathrm{~N} \mathrm{NaOH}$. Distilled water was added to bring the volume to $50 \mathrm{ml}$. The same stock solution concentration used for NAA was for $\mathrm{GA}_{3}$ and BAP but the latter two were dissolved in water. After hormone addition, $\mathrm{pH}$ was adjusted to $5.6-5.8$ using $0.1 \mathrm{M} \mathrm{NaOH}$. The prepared media was poured into universal bottles (10 $\mathrm{ml}$ of media each) and sterilised by autoclaving for 15 minutes at $121^{\circ} \mathrm{C}$

Culture conditions: After the meristems had been cultured onto the respective media treatments, the meristem cultures were moved to the growth room where temperature was kept at $25 \pm 3^{\circ} \mathrm{C}$ and a 16 hour light: 8 hour dark photoperiod was maintained. The experiment was laid out into a Randomised Complete Block Design (RCBD) with three blocks and nine treatments (Table 1). The treatments were replicated at least nine times in each block to give a total of 243 experimental units. Blocking was done against light. After ten weeks in culture, the following plant parameters were recorded: treatment effect on calli production, on root production, on shoot production, on plant height, on multiple shoot production, on node production and on number of leaves per regenerated plant. Figure 7 depicts the progressive growth and development of Brondal meristems on MS media in the 10 weeks of culture. 


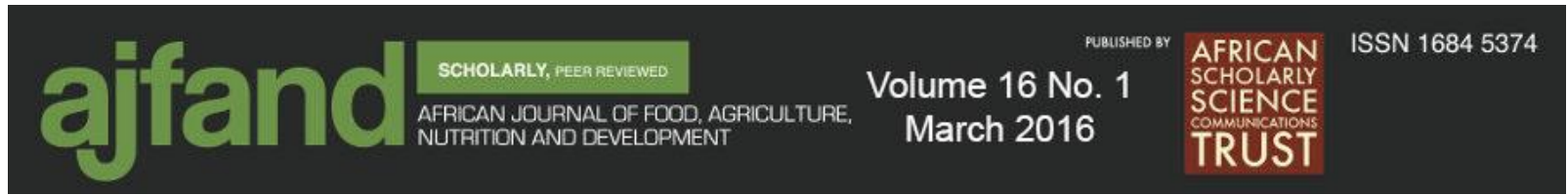

Statistical Analysis: Data obtained was subjected to statistical analysis using Friedman's non-parametric test. Since only one meristematic dome was cultured into each universal bottle, the total number of experimental units was 243.

\section{RESULTS}

Assessing the shoot regenerative capacity of nine hormonal treatments on Brondal meristem tissue

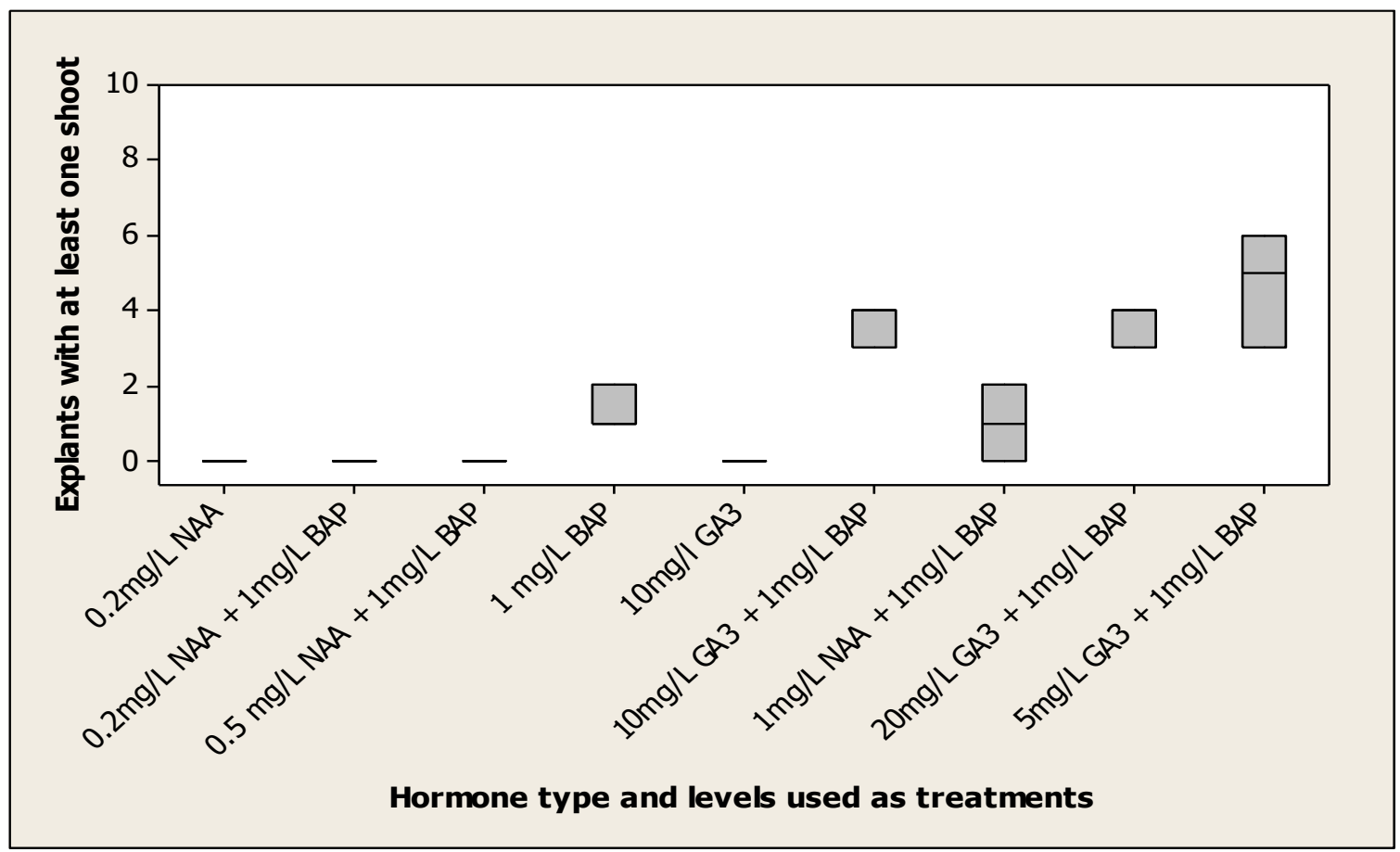

Figure 1: Effect of NAA, BAP and GA3 either alone or in combinations on shoot regenerative capacity of Brondal Sweet potato meristems 10 weeks after culture

Based on Friedman's non-parametric test, there was a highly significant $(p<0.01)$ difference between treatments used to induce shoots from meristematic tissue. As depicted by Figure 1 three treatments, $10 \mathrm{mg}^{-} \mathrm{L} \mathrm{GA} 3+1 \mathrm{mg}^{-} \mathrm{L}$ BAP; $20 \mathrm{mg}^{-} \mathrm{L} \mathrm{GA}_{3}+1$ $\mathrm{mg}^{-} \mathrm{L}$ BAP and $5 \mathrm{mg}^{-} \mathrm{L} \mathrm{GA}_{3}+1 \mathrm{mg}^{-} \mathrm{L}$ BAP induced an average of 3-6 shoots per nine meristems cultured. These three treatments were not significantly different from each other. There was also no significant difference between treatments $1 \mathrm{mg}^{-} \mathrm{L}$ BAP and 1 $\mathrm{mg}^{-} \mathrm{L}$ NAA $+1 \mathrm{mg}^{-} \mathrm{L}$ BAP. Both treatments had an average of one shoot per nine meristems cultured. Treatments $0.2 \mathrm{mg} / \mathrm{L} \mathrm{NAA} ; 0.2 \mathrm{mg} / \mathrm{L} \mathrm{NAA}+1 \mathrm{mg} / \mathrm{L} \mathrm{BAP} ; 0.5 \mathrm{mg} / \mathrm{L}$ $\mathrm{NAA}+1 \mathrm{mg} / \mathrm{L} \mathrm{BAP}$ and $10 \mathrm{mg} / \mathrm{L} \mathrm{GA}_{3}$ all failed to induce a single shoot from all nine cultured meristems and thus were not significantly different from each other. Treatments $0.2 \mathrm{mg} / \mathrm{L} \mathrm{NAA} ; 0.2 \mathrm{mg} / \mathrm{L} \mathrm{NAA}+1 \mathrm{mg} / \mathrm{L} \mathrm{BAP} ; 0.5 \mathrm{mg} / \mathrm{L} \mathrm{NAA}+1 \mathrm{mg} / \mathrm{L}$ BAP and 10 $\mathrm{mg} / \mathrm{L} \mathrm{GA} 3$ were all not significantly different from treatment $1 \mathrm{mg} / \mathrm{L} \mathrm{NAA}+1 \mathrm{mg} / \mathrm{L}$ BAP, where shoot regeneration was concerned. 


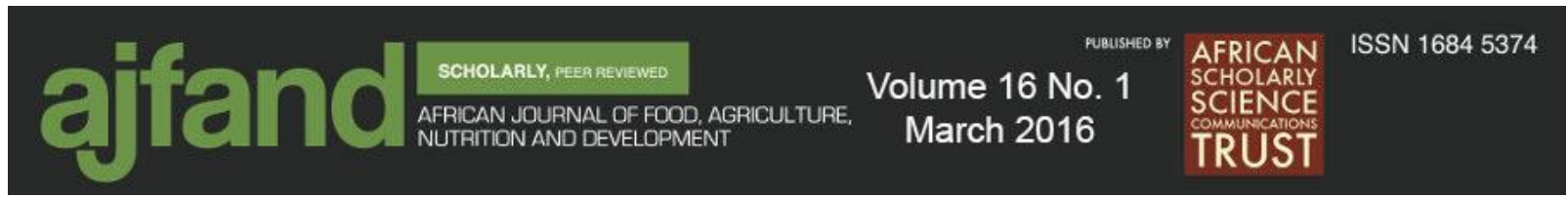

Evaluating the capability of treatments used to promote multiple shoot production from a single meristem

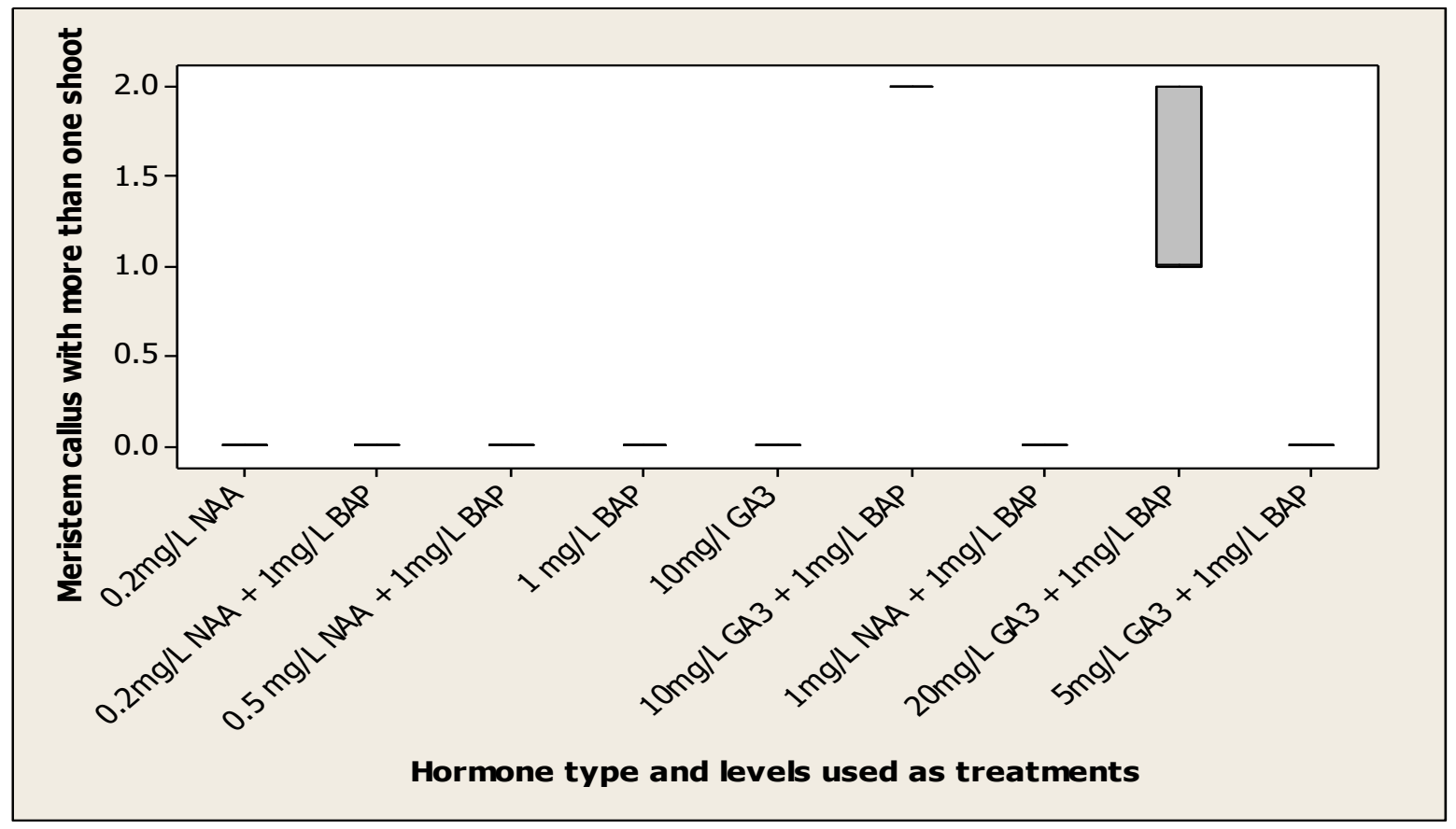

Figure 2: Effect of hormonal treatments on multiple shoot production from a single cultured meristem of Brondal sweet potato at 10 weeks after culture

Friedman's non-parametric test showed that there was a highly significant $(\mathrm{p}<0.01)$ difference in the capacity of treatments to induce multiple shoot production from Brondal meristems. Figure 2 shows treatments falling into two distinct groups which were significantly $(\mathrm{p}=<0.01)$ different from each other. The first group had two treatments, 10 $\mathrm{mg}^{-} \mathrm{L} \mathrm{GA}_{3}+1 \mathrm{mg}^{-} \mathrm{L}$ BAP and $20 \mathrm{mg}^{-} \mathrm{L} \mathrm{GA}_{3}+1 \mathrm{mg}^{-} \mathrm{L}$ BAP, while the remaining seven treatments used fell into the second group. In the first group, both treatments were able to promote multiple shoot production from cultured meristems with $10 \mathrm{mg}^{-} \mathrm{L} \mathrm{GA}_{3}+1$ $\mathrm{mg}^{-} \mathrm{L}$ BAP and $20 \mathrm{mg}^{-} \mathrm{L} \mathrm{GA}_{3}+1 \mathrm{mg}^{-} \mathrm{L}$ BAP inducing at most three and two shoots per meristem, respectively. This was in sharp contrast with the second group, which was incapable of inducing multiple shoot production and at most could produce just one shoot per meristem. 


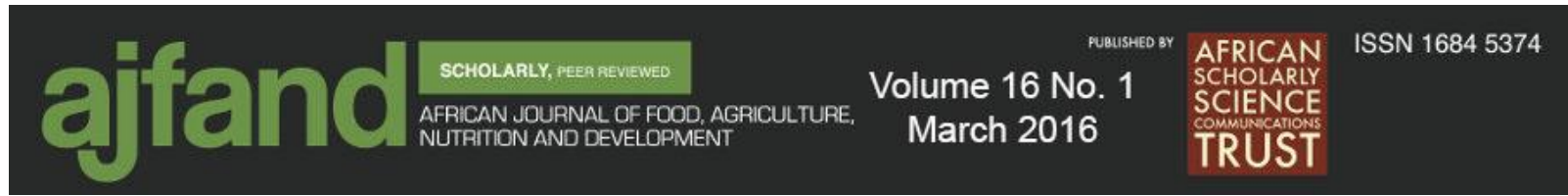

Determining the total number of plantlets produced from meristems per treatment

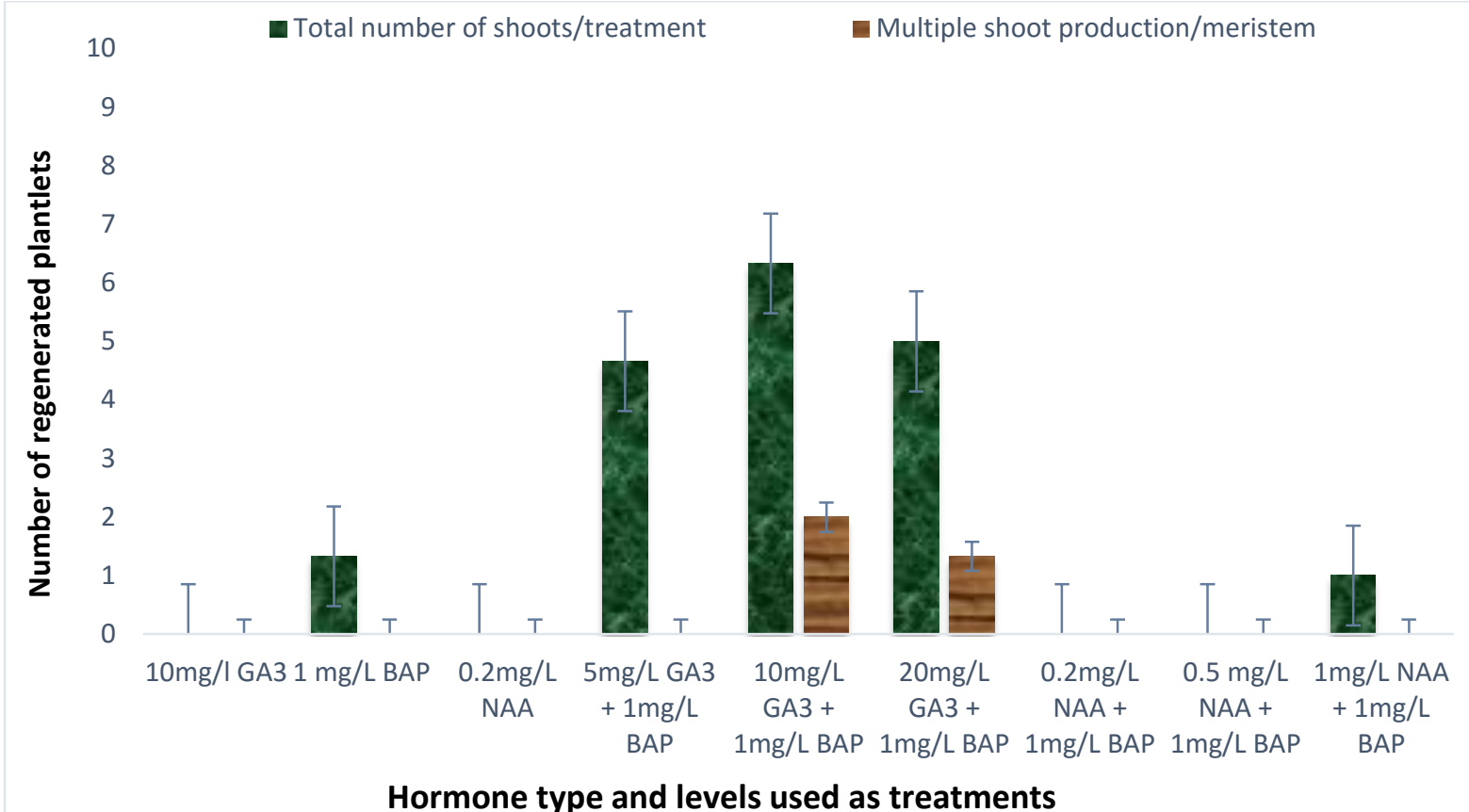

Figure 3: Effect of hormonal treatments, NAA, BAP and GA3 either alone or in combination, on overall total number of plantlets derived per treatment from cultured Brondal meristems 10 weeks after culture

Figure 3 shows the total number of shoots produced per treatment, highlighting the treatments that were able to induce multiple plantlet production. Treatment $10 \mathrm{mg}^{-} \mathrm{L} \mathrm{GA}_{3}$ $+1 \mathrm{mg}^{-} \mathrm{L}$ BAP produced the largest total number of shoots (an average of six shoots) compared to any other treatment. This was followed by treatments $20 \mathrm{mg}^{-} \mathrm{L} \mathrm{GA}_{3}+1 \mathrm{mg}^{-}$ $\mathrm{L}$ BAP and $5 \mathrm{mg}^{-} \mathrm{L} \mathrm{GA}_{3}+1 \mathrm{mg}^{-} \mathrm{L}$ BAP with each treatment producing a total of five and four shoots, respectively. Treatments $1 \mathrm{mg}^{-} \mathrm{L}$ BAP and $1 \mathrm{mg}^{-} \mathrm{L}$ NAA $+1 \mathrm{mg}^{-} \mathrm{L}$ BAP produced a total of one shoot per nine meristems cultured within that treatment. The rest of the treatments were unable to induce any shoot production from meristems. With regard to multiple shoot production, only treatments $10 \mathrm{mg}^{-} \mathrm{L} \mathrm{GA}_{3}+1 \mathrm{mg}^{-} \mathrm{L}$ BAP and 20 $\mathrm{mg}^{-} \mathrm{L} \mathrm{GA}_{3}+1 \mathrm{mg}^{-} \mathrm{L}$ BAP were competent at promoting multiple shoot production from single meristem. 


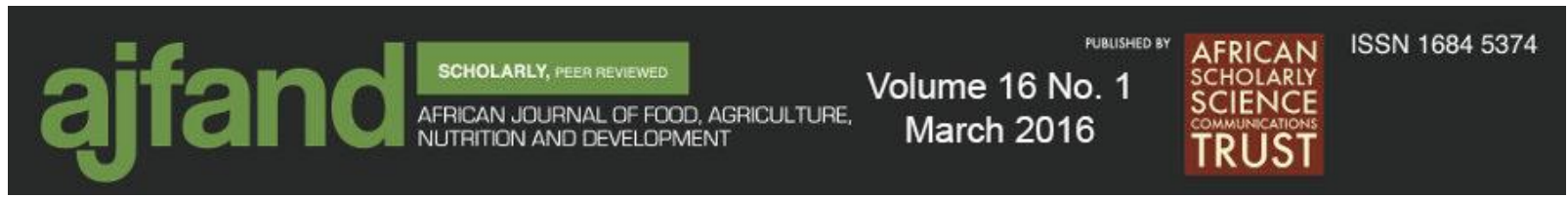

Assessing the effect of nine hormonal treatments on plant height of adventitious shoots regenerated from cultured Brondal meristem tissue

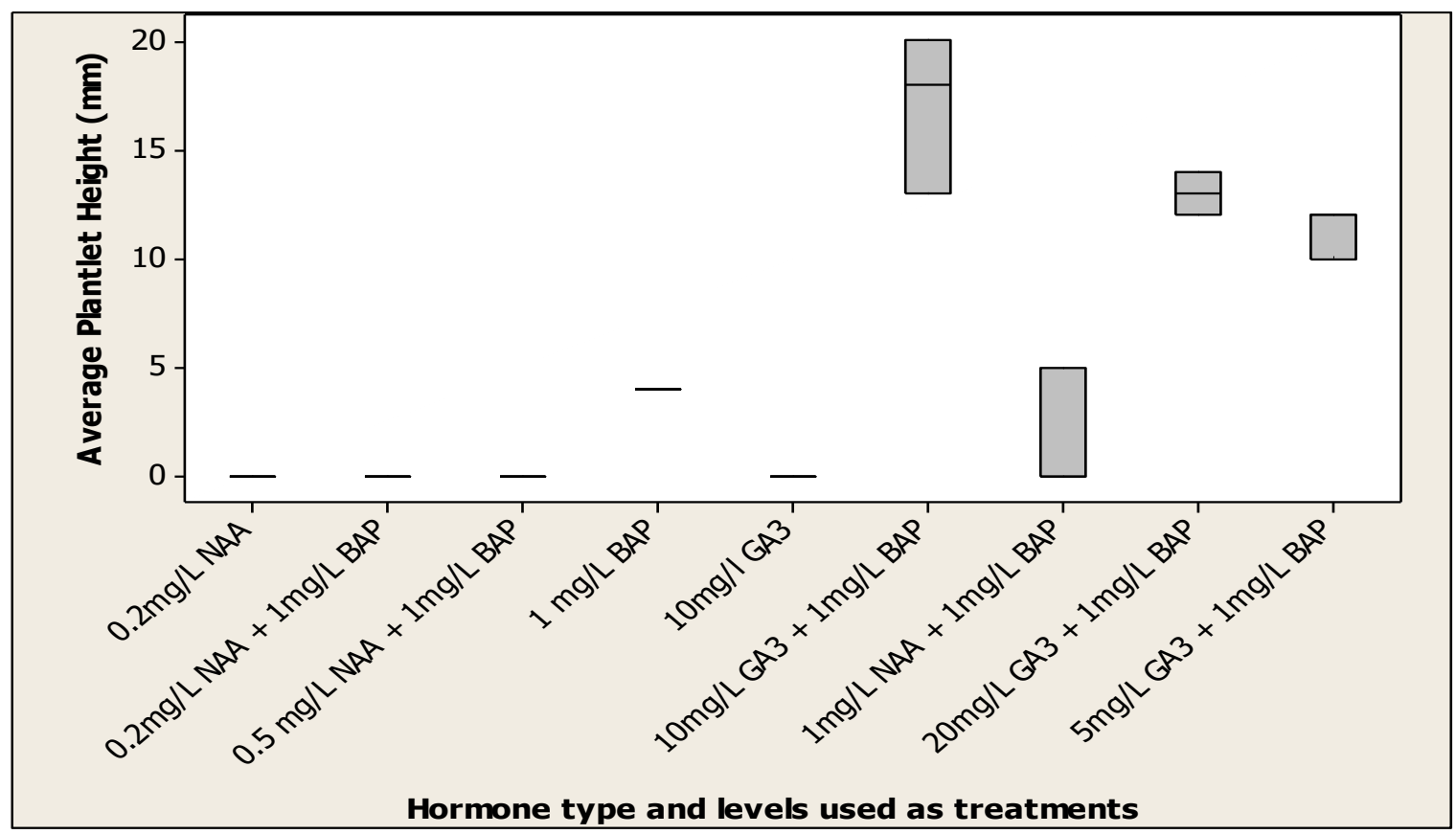

Figure 4: Effect of hormonal treatments, NAA, BAP and GA3 either alone or in combination, on plant height of adventitious shoots derived from cultured meristems of Brondal sweet potato at ten weeks after culture

Figure 4 shows the average plant height in $(\mathrm{mm})$ of shoots produced from treatments on meristematic tissue. Freidman's non-parametric test revealed that there was a highly significant $(\mathrm{p}<0.01)$ difference between treatments used. As in the assessments done above, treatments $10 \mathrm{mg}^{-} \mathrm{L} \mathrm{GA}_{3}+1 \mathrm{mg}^{-} \mathrm{L}$ BAP and $20 \mathrm{mg}^{-} \mathrm{L} \mathrm{GA}_{3}+1 \mathrm{mg}^{-} \mathrm{L}$ BAP were not significantly different from each other, producing the tallest shoots in the experiment, which ranged from 12-20 mm. Treatment $20 \mathrm{mg}^{-} \mathrm{L} \mathrm{GA}_{3}+1 \mathrm{mg}^{-} \mathrm{L}$ BAP was, however, not significantly different from $5 \mathrm{mg}^{-} \mathrm{L} \mathrm{GA}_{3}+1 \mathrm{mg}^{-} \mathrm{L}$ BAP, with treatment $5 \mathrm{mg}^{-} \mathrm{L} \mathrm{GA}_{3}$ $+1 \mathrm{mg}^{-} \mathrm{L}$ BAP producing shoots with heights ranging from $10-14 \mathrm{~mm}$. There was no significant difference between treatments $1 \mathrm{mg}^{-} \mathrm{L}$ BAP and $1 \mathrm{mg}^{-} \mathrm{L}$ NAA $+1 \mathrm{mg}^{-} \mathrm{L}$ BAP with both treatments producing shoots with heights ranging from $0.4-0.3 \mathrm{~mm}$. Since treatments $0.2 \mathrm{mg}^{-} \mathrm{L}$ NAA; $0.2 \mathrm{mg}^{-} \mathrm{L} \mathrm{NAA}+1 \mathrm{mg}^{-} \mathrm{L}$ BAP; $0.5 \mathrm{mg}^{-} \mathrm{L} \mathrm{NAA}+1 \mathrm{mg}^{-} \mathrm{L}$ BAP and $10 \mathrm{mg}^{-} \mathrm{L} \mathrm{GA}_{3}$ all failed to induce any shoot production from cultured meristems, no plant heights were recorded for these treatments. 


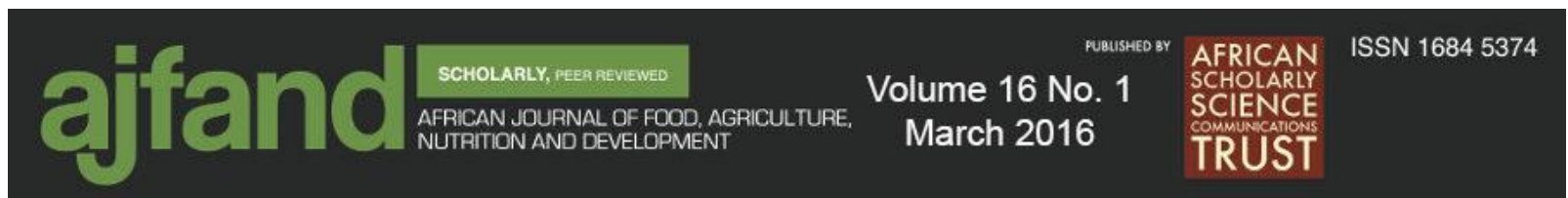

Determining treatment effect on average number of leaves produced from regenerated adventitious shoots

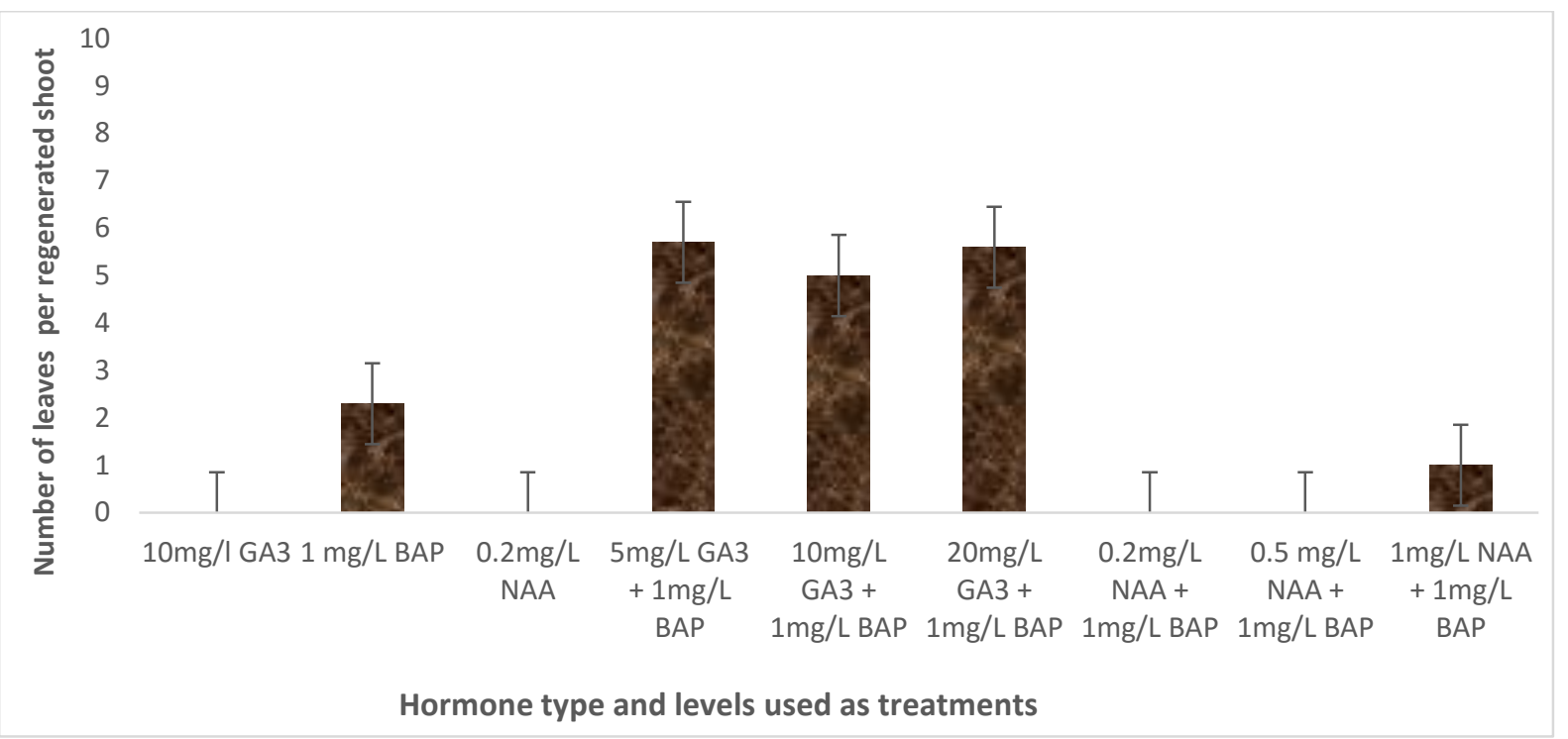

Figure 5: Effect of hormonal treatments on average number of leaves produced from regenerated adventitious shoots that originated from cultured meristems of Brondal sweet potato at ten weeks after culture

With regards to average leaf number/shoot, there was no significant difference $(p>0.01)$ between treatments $10 \mathrm{mg}^{-} \mathrm{L} \mathrm{GA}_{3}+1 \mathrm{mg}^{-} \mathrm{L}$ BAP; $20 \mathrm{mg}^{-} \mathrm{L} \mathrm{GA}_{3}+1 \mathrm{mg}^{-} \mathrm{L}$ BAP and $5 \mathrm{mg}^{-}$ $\mathrm{L} \mathrm{GA}_{3}+1 \mathrm{mg}^{-} \mathrm{L}$ BAP. The average leaf number for these three treatments were 4-6 leaves per plantlet. Treatments $1 \mathrm{mg}^{-} \mathrm{L}$ BAP and $1 \mathrm{mg}^{-} \mathrm{L}$ NAA $+1 \mathrm{mg}^{-} \mathrm{L} \mathrm{g} / \mathrm{L}$ BAP were also not significantly $(\mathrm{p}>0.01)$ different from each other, producing an average of 1-3 leaves/shoot. Treatments $0.2 \mathrm{mg}^{-} \mathrm{L}$ NAA; $0.2 \mathrm{mg}^{-} \mathrm{L}$ NAA + $1 \mathrm{mg}^{-} \mathrm{L}$ BAP; $0,5 \mathrm{mg}^{-} \mathrm{L}$ NAA $+1 \mathrm{mg}^{-} \mathrm{L}$ BAP and $10 \mathrm{mg}^{-} \mathrm{L} \mathrm{GA}_{3}$ all failed to induce any shoot production from cultured meristems, no leaves could be recorded for these treatments. 


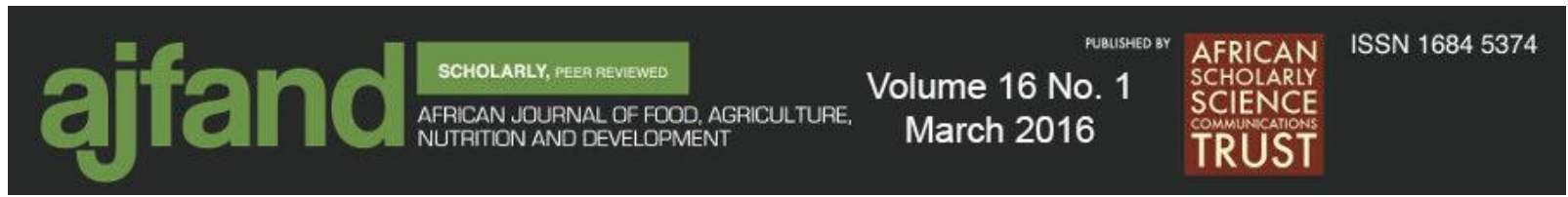

Treatment effect on average number of nodes produced from regenerated adventitious shoots of Brondal

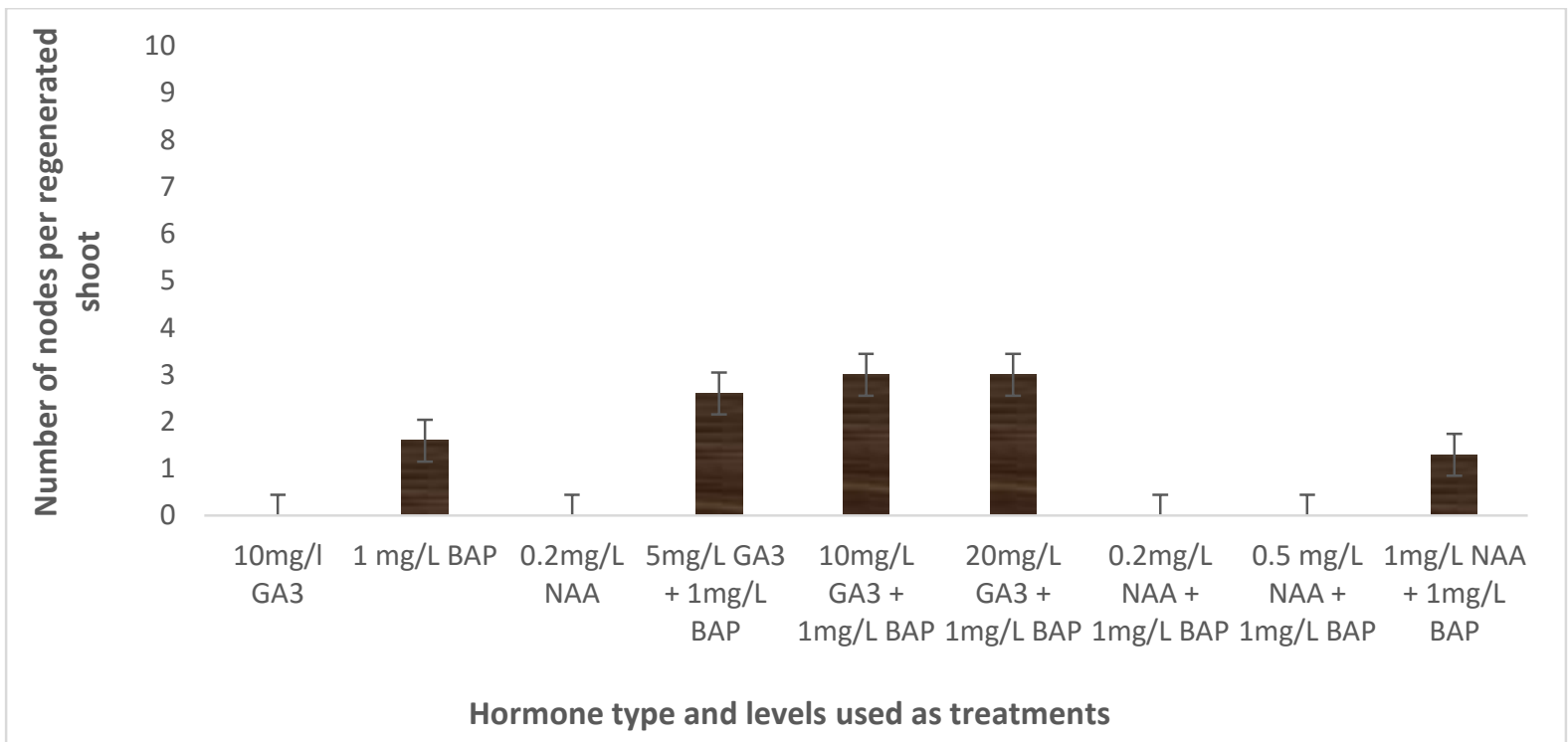

Figure 6: Hormonal influence of NAA, BAP and GA3 (alone or in combination) on average number of nodes produced from regenerated adventitious shoots of Brondal ten weeks after culture

Figure 6 shows that treatments $10 \mathrm{mg}^{-} \mathrm{L} \mathrm{GA}_{3}+1 \mathrm{mg}^{-} \mathrm{L}$ BAP and $20 \mathrm{mg}^{-} \mathrm{L} \mathrm{GA}_{3}+1 \mathrm{mg}^{-} \mathrm{L}$ BAP had the highest number of nodes per shoot with an average of 3 nodes per shoot each. This was closely followed by treatments $5 \mathrm{mg}^{-} \mathrm{L} \mathrm{GA}_{3}+1 \mathrm{mg}^{-} \mathrm{L}$ BAP, $1 \mathrm{mg}^{-} \mathrm{L}$ BAP and $1 \mathrm{mg}^{-} \mathrm{L} \mathrm{NAA}+1 \mathrm{mg}^{-} \mathrm{L}$ BAP with average node numbers 3,2 , and 1 node/shoot, respectively. Since treatments $0.2 \mathrm{mg}^{-} \mathrm{L}$ NAA; $0.2 \mathrm{mg} / \mathrm{L}$ NAA $+1 \mathrm{mg}^{-} \mathrm{L}$ BAP; $0.5 \mathrm{mg}^{-} \mathrm{L}$ $\mathrm{NAA}+1 \mathrm{mg}^{-} \mathrm{L}$ BAP and $10 \mathrm{mg}^{-} \mathrm{L} \mathrm{GA}_{3}$ all failed to induce any shoot production from cultured meristems, no nodes could be recorded for these treatments. 

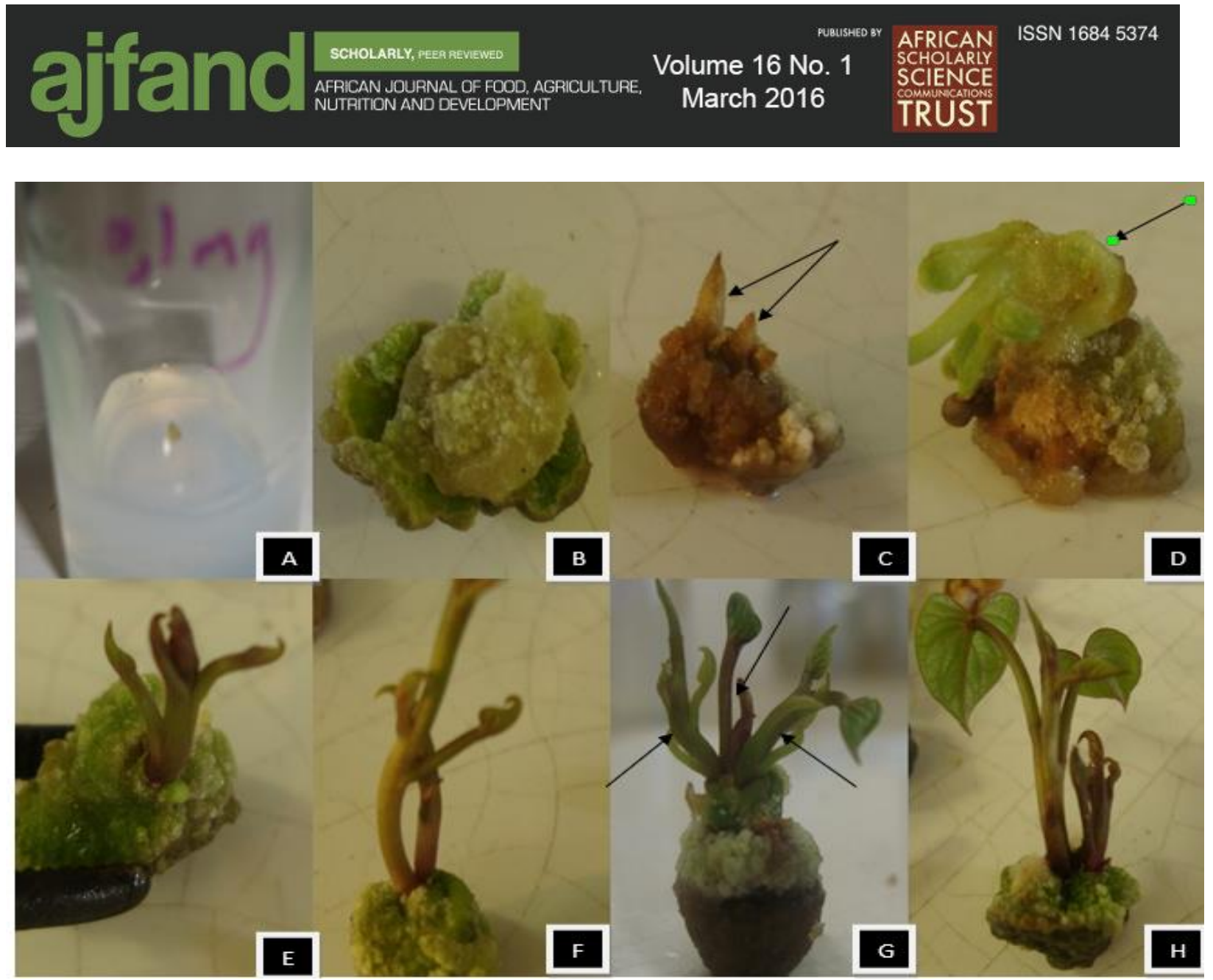

Figure 7: Regenerating sweet potato ( $c v$ Brondal) on Murashige and Skoog media from culture initiation to plantlet formation. A) Sweet potato meristem cultured in a universal bottle. B) A callusing meristematic dome after two weeks on MS media. C) Shoot initials emerging from callus. D) Shoot development four weeks after meristem culture. E) Shoot development after six weeks of meristem culture. $\mathbf{F}-\mathbf{H}$ ) The growth of multiple shoots (F showing two shoots, $\mathbf{G}$ showing three shoots, $\mathbf{H}$ showing two shoots) from a single cultured meristem

\section{DISCUSSION}

Plant hormones exert profound morphological effects on plant growth and development, the precise action depending on the type and concentration of the hormone and the sensitivity of the organ involved [13]. In this study, the effect of BAP, GA 3 and NAA, either in combination or alone, on cultured Brondal meristems was investigated.

Shoot induction from Brondal meristems was only achieved in treatments containing either BAP alone or when BAP was combined with either NAA (at $1 \mathrm{mg}^{-} \mathrm{L}$ ) or with $\mathrm{GA}_{3}$ (at 5,10 , or $20 \mathrm{mg}^{-} \mathrm{L}$ ). Of the shoot producing treatments, the BAP $+\mathrm{GA}_{3}$ treatments produced significantly $(\mathrm{p}<0.01)$ more shoots than any other treatment tested. These results are consistent with the findings of several researchers such as, Alam et al. [14] and Bhuuyan et al. [15] both working with potato, Jesmin et al. [16] working on Mexican daisy as well as Safdari and Kazentabra [17] working on Mose rose. Similar to the 


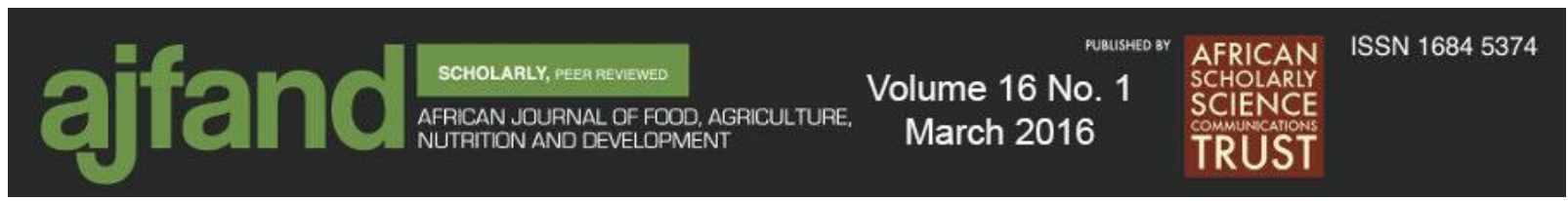

aforementioned researchers' findings, this study found that the presence of BAP in media enhanced a key contributing factor for plant shoot production from meristems. Research has shown that when the hormone BAP is used in tissue culture, it promotes physiological processes that aid plant development. For instance, the presence of BAP has been linked to enhanced protein synthesis and heightened polysome function. In addition, BAP has also been found to stimulate the activity of RNA polymerase [18].

It was also found that in the $\mathrm{BAP}+\mathrm{GA}_{3}$ treatments, doubling the $\mathrm{GA}_{3}$ content from 5 to $10 \mathrm{mg}^{-} \mathrm{L}$ served to increase the number of plantlets produced from any given meristem that already had the potential to produce shoots. Continued doubling of the $\mathrm{GA}_{3}$ content from 10 to $20 \mathrm{mg}^{-} \mathrm{L}$ in media, still led to multiple shoot production albeit at a much lower level than $\mathrm{GA}_{3}$ at $10 \mathrm{mg}^{-} \mathrm{L}$. These results were similar to the findings of Dugassa and Feyisa [19] working on sweet potato as well as Pattinaik and Chand [20] working on Marus species respectively. Valles and Boxus [21] working on rose hybrids stated that the presence of $\mathrm{GA}_{3}$ served to increase the number of organs formed and that with roses, although BAP was enough to cause shooting, the additional presence of $\mathrm{GA}_{3}$ lead to a multiplication in the number of possible shoots that could emerge from a given meristem.

Regarding plant height, the shoots produced on $\mathrm{GA}_{3}$ containing treatments were significantly $(\mathrm{p}<0.01)$ taller than shoots produced in non-GA 3 treatments. In addition, the $\mathrm{GA}_{3}$ treated shoots had significantly more nodes and leaves on the plant stems compared to shoots produced in non-GA $\mathrm{G}_{3}$ treatments. Meher et al. [22] working on Chrysanthemums and Hutchison et al. [23] working on the cut flower Alstroemeria aurantiaca also found that plants produced in media containing $\mathrm{GA}_{3}$ tended to have elongated plant stems compared to plants from non-GA 3 treatments. $\mathrm{GA}_{3}$ treated plants are taller as compared to non-GA $\mathrm{G}_{3}$ treated plants because $\mathrm{GA}_{3}$ tends to increase cell elongation by causing changes in cell wall extensibility which is the irreversible extension of the wall [24]. Treatments without $\mathrm{GA}_{3}$ but containing BAP alone tended to be shorter in statue because cytokines encourage growth mainly through promoting cell division at the expense of not cell expansion [25].

Naeem et al. [26] also pointed out that $\mathrm{GA}_{3}$ treated shoots were not only taller but also generally tended to have more nodes on the stem compared to the number of nodes on a stem on non-GA $A_{3}$ treated shoots. Naeem et al. [26] attributed the appearance of more nodes on $\mathrm{GA}_{3}$ treated plants to the fact that elongation in shoot length serves to stretch out the stem, thereby enabling the visibility of nodes that could perhaps be embedded within the meristem calli.

Pertaining to the number of leaves that developed per regenerated Brondal plantlet, this study showed that $\mathrm{GA}_{3}$ played a strong promoting role in the visibility, expansion and number of leaves developed from regenerated shoots. This was in agreement with the findings of Bhuiuyan et al. [15] in potato and Naeem et al. [26] working on lentils, who found that the presence of $\mathrm{GA}_{3}$ in plant regeneration media increased the number of compound leaves and assisted in leaf expansion and aided the visibility of the leaves enough to be counted. George et al. [18] goes on further to say that in the absence of 


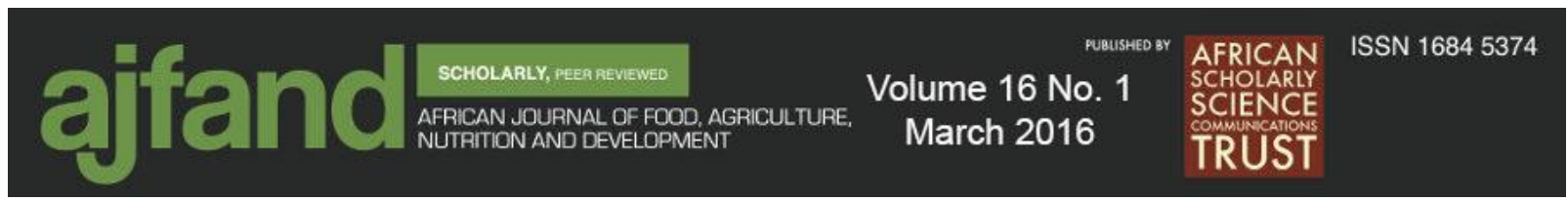

$\mathrm{GA}_{3}$, the regenerated leaves tend to be small, deformed and the plant itself develops short internodes.

\section{CONCLUSION}

In this study the effect of BAP, NAA and $\mathrm{GA}_{3}$ either alone or in combination, on sweet potato variety Brondal meristem culture were evaluated. Where plantlet regeneration was concerned, all treatments containing a combination of $1 \mathrm{mg}^{-} \mathrm{L}$ BAP and $\mathrm{GA}_{3}$ (at $5 \mathrm{mg}^{-} \mathrm{L}$, $10 \mathrm{mg}^{-} \mathrm{L}$, or $20 \mathrm{mg}^{-} \mathrm{L}$ ) stimulated the production of the highest number of plantlets compared to any other hormone or hormonal combination. Only treatments $10 \mathrm{mg}^{-} \mathrm{LGA}_{3}$ $+1 \mathrm{mg}^{-} \mathrm{L}$ BAP and $20 \mathrm{mg}^{-} \mathrm{L} \mathrm{GA}_{3}+1 \mathrm{mg}^{-} \mathrm{L}$ BAP induced multiple shoot production per meristem. The tallest plants (at $20 \mathrm{~mm}$ ) were produced on treatment $10 \mathrm{mg}-\mathrm{L} \mathrm{GA}_{3}+1$ mg-L BAP. Where average number of leaves per shoot was concerned, all treatments containing a combination of $1 \mathrm{mg}^{-} \mathrm{L}$ BAP and $\mathrm{GA}_{3}$ (at $5 \mathrm{mg}^{-} \mathrm{L}, 10 \mathrm{mg}^{-} \mathrm{L}$, or $20 \mathrm{mg}^{-} \mathrm{L}$ ) were capable of promoting high numbers of leaves per shoot reaching up to six leaves per shoot. The highest node number per shoot was achieved by treatments $10 \mathrm{mg}^{-} \mathrm{L} \mathrm{GA}_{3}$ $+1 \mathrm{mg}^{-} \mathrm{L}$ BAP and $20 \mathrm{mg}^{-} \mathrm{L} \mathrm{GA}_{3}+1 \mathrm{mg}^{-} \mathrm{L}$ BAP, giving rise to three nodes per regenerated shoot in 10 weeks of culture. Overall, the best hormonal treatment for the culture of Brondal meristems was $10 \mathrm{mg}^{-} \mathrm{L} \mathrm{GA} 3+1 \mathrm{mg}^{-} \mathrm{L}$ BAP hormonal treatment combination which proved to be the most effective treatment for micro-propagation of shoots from Brondal as it resulted in high shoot regeneration frequency and multiple shoot production from cultured meristems.

\section{RECOMMENDATIONS}

It is recommended that the hormonal treatment $10 \mathrm{mg}^{-} \mathrm{L} \mathrm{GA}_{3}+1 \mathrm{mg}^{-} \mathrm{L}$ BAP be used for the mass generation of virus free sweet potato variety Brondal which can then be distributed to the farmers for cultivation. Since the experiment was repeated three times (not shown), to check for reproducibility and the results found to be consistent, it is recommended that meristem culture also be performed on other high yielding sweet potato varieties found in Zimbabwe and in the region using the hormonal levels $10 \mathrm{mg}$ $\mathrm{L} \mathrm{GA}_{3}+1 \mathrm{mg}^{-} \mathrm{L}$ BAP as a basis. Further, it is recommended that the meristem derived regenerated plantlets be subjected to field trials to evaluate yield performance in the field.

\section{ACKNOWLEDGEMENTS}

At the University of Zimbabwe, we wish to thank the Crop Science Chairman, Professor. U. Mazarura for providing us with laboratory and culture room facilities to undertake our tissue culture experiments. We would also like to thank DAAD for financially supporting the study. 
Table 1: Treatment number and corresponding hormone concentrations/combinations in MS Media used to induce plant regeneration from cultured Brondal meristems

Hormone type and hormone level

\begin{tabular}{|c|c|}
\hline 1 & $10 \mathrm{mg}^{-} \mathrm{L} \mathrm{GA}_{3}$ \\
\hline 2 & $1 \mathrm{mg}^{-} \mathrm{L}$ BAP \\
\hline 3 & $0.2 \mathrm{mg}^{-} \mathrm{L}$ NAA \\
\hline 4 & $1 \mathrm{mg}^{-} \mathrm{L} \mathrm{BAP}+5 \mathrm{mg}^{-} \mathrm{L} \mathrm{GA}_{3}$ \\
\hline 5 & $1 \mathrm{mg}^{-} \mathrm{L} \mathrm{BAP}+10 \mathrm{mg}^{-} \mathrm{L} \mathrm{GA}_{3}$ \\
\hline 6 & $1 \mathrm{mg}^{-} \mathrm{L}$ BAP $+20 \mathrm{mg}^{-} \mathrm{L} \mathrm{GA}_{3}$ \\
\hline 7 & $1 \mathrm{mg}^{-} \mathrm{L} \mathrm{BAP}+0.2 \mathrm{mg}^{-} \mathrm{L}$ NAA \\
\hline 8 & $1 \mathrm{mg}^{-} \mathrm{L} \mathrm{BAP}+0.5 \mathrm{mg}^{-} \mathrm{L} \mathrm{NAA}$ \\
\hline 9 & $1 \mathrm{mg}^{-} \mathrm{L}$ BAP $+1 \mathrm{mg}^{-} \mathrm{L}$ NAA \\
\hline
\end{tabular}




\section{LIST OF ABBREVIATIONS}

$\begin{array}{ll}\text { BAP } & \text { Benzyl amino purine } \\ \mathrm{GA}_{3} & \text { Gibberellic acid } \\ \text { MS } & \text { Murashige and Skoog media } \\ \text { NAA } & \text { 1-Naphthaleneacetic Acid }\end{array}$




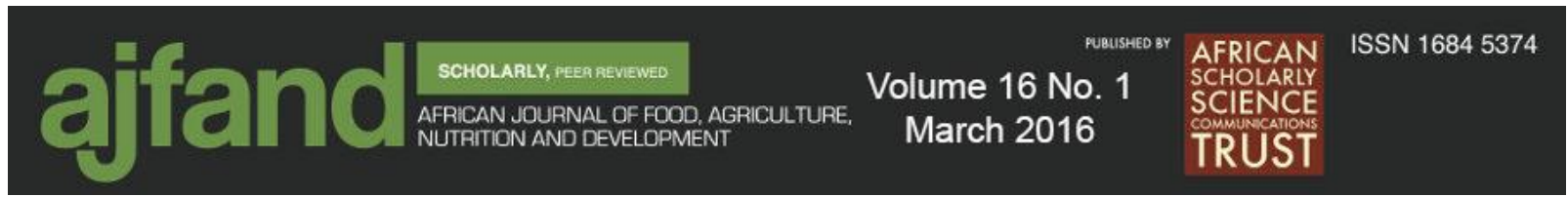

\section{REFERENCES}

1. Huaccho L and RJ Hijmans A Geo-Referenced Database of Global Sweet potato Distribution. Production Systems and Natural Resource Management Department International Potato Centre (CIP), Working Paper No. 4. 2000.

2. Woolfe JA Sweet potato: an untapped food resource. Cambridge University Press, Cambridge, 1992: 643.

3. Oggema JN, Kinyua MG, Ouma JP and JO Owuoche Agronomic performance of locally adapted sweet potato (Ipomoea batatas(L.) Lam.) cultivars derived from tissue culture regenerated plants. AJB. 2007;6:1418-1425.

4. Lerner RB The Sweet potato. Purdue University Cooperative Extension Service. 2011: http://www.hort.purdue.edu/ext/ho-136.pdf. Retrieved on $14^{\text {th }}$ August, 2014.

5. Factfish Zimbabwe: Sweet potatoes, production quantity. http://www.factfish.com/statisticco. Retrieved on $20^{\text {th }}$ March, 2015.

6. International service for the acquisition of Agri-biotech Applications (ISAAA). 2005: http://www.iassa.org/index.php Retrieved on 12 ${ }^{\text {th }}$ May, 2015.

7. Ministry of Lands and Agriculture, Department of Agricultural Research and Extension (AREX) An overview of Zimbabwe's agriculture. Harare, Zimbabwe: 2008.

8. Kreuze KF, Valkonen JPT and $\mathbf{P}$ Ghislain Genetic Engineering. In: G. Loebenstein and G. Thottappilly (Eds). The Sweetpotato. Springer-Verlag, New York, 2009: 552.

9. Pazarlar S, Gümüş $\mathbf{M}$ and $\mathbf{G}$ B Öztekin Effects of Tobacco mosaic virus Infection on Growth and Physiological Parameters in Some Pepper Varieties (Capsicum annuum L.). Not Bot HortiAgrobo. 2013; 41:427-433.

10. Gosukonda RM, Porobodessai A, Blay E and CS Prakash Thidiazuron-induced adventitious shoot regeneration of sweet potato (Ipomoea batatas). In vitro Cellu. \& Develop. Biol. 1997;31: 65-71.

11. Zhang L Propagation system and production techniques of virus-free seed sweet potato. Chinese Sweet potato Brief, 1996:67-71.

12. Murashige T and F Skoog A revised medium for rapid growth and bioassay with tobacco tissue culture. PhysiolPlant.1964; 5:473-497.

13. Addae-Frimpomaah F, Amponash J and TK Tenrey Regeneration of three sweet potato (Ipomea batatas) accessions in Ghana via meristem and nodal sections. J. Plant Breed.Crop Sci.2014; 8: 121-138. 


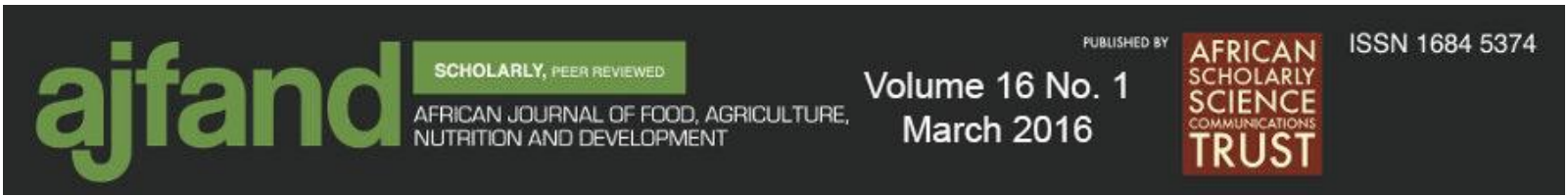

14. Alam AI, Sharmin SA, Naher MK, Alam MJ, Anisuzzaman M and MJ Alam Effect of growth regulators on meristem culture and plantlet establishment in sweet potato Ipomoea batatas(L.) POJ.2013; 3:35-39.

15. Bhuuyan FR In vitro meristem culture and regeneration of three potato varieties of Bangladesh. Res Biotechnol.2013; 4: 29-37.

16. Jesmin S, Sarker AQ and MF Alam Multiple shoot proliferation in Tridax procumbens L. through in vitro methods. Int J Bio Sci. 2013; 37: 177-187.

17. Safdari Y and SK Kazentabr Direct shoot regeneration, callus induction and plant regeneration from callus tissue in Mose rose (Portulaca grandiflora L.) POJ.2013; 3:45-51.

18. George EF, Hall MA and G De Klerk The Components of Plant Tissue Culture Media II: Organic Additions, Osmotic and pH Effects, and Support Systems. Plants propagation by tissue culture. $3^{\text {rd }}$ Edition, Springer. 2008: 115-173.

19. Dugassa G and T Feyisa In vitro production of virus-free sweet potato [Ipomoea batatas (1.)] by meristem culture and thermotherapy. SINET: Ethiop. J. Sci.2013; 34: 17-28.

20. Pattnaik SK and PK Chand Rapid clonal propagation of three mulberries Morusca thayanain vitro culture of apical shoot buds and nodal explants from mature trees. Plant Cell Rep. 1997; 16: 503-508.

21. Valles M and P Boxus Micropropagation of several Rosa hybrid L. cultivars. Acta Hort. 1987; 212: 611-617.

22. Meher SP, Jiotode DJ, Turkhede, AB, Darange SO, Ghatol PU and CS Dhawad Effect of planting time and growth regulator treatments on flowering and yield of Chrysanthemum. Crop Res. Hissar.1999; 18: 345-348.

23. Hutchinson MJ, Onamu R, Kipkosgei L and SD Obukosia Effect of Thidiazuron, NAA and BAP on in vitro Propagation of Alstroemeria aurantiaca $c v$. 'Rosita' from shoot tip explants. JAGST.2010;12: 2.

24. Stuart DA and RL Jones Roles of extensibility and turgor in gibberellin- and dark-stimulated growth. Plant Physiol. 1977; 59: 61- 68.

25. Perrot-Rechenmann C. "Cellular responses to auxin: division versus expansion." Cold Spring Harbor perspectives in biology. 2010: a001446.

26. Naeem M, Bhatti I, Hafeez R, Ahmad M and M Yasin Ashraf Effect of some growth hormones (GA3, IAA and kinetin) on the morphology and early or delayed initiation of bud of lentil (Lens culinaris medik). Pak. J. Bot.2008;36: 801-809. 